VIII. Descriptions of Chalcidites. By Francis WaLker, Esq., F.L.S. \& c. \& c.

\author{
Read June 17th, 1845.
}

THE following communication contains a description of species not included in my previous publications on Chalcidites in the 'Entomological Magazine,' the 'Annals of Natural History,' the 'Entomologist,' and the 'Monographia Chalciditum.' In these works further information will be found respecting the genera and species mentioned as being related to those here described.

\title{
Pteromalus, Swederus.
}

This genus comprises a great number of species, somewhat similar in structure, and having, comparatively speaking, one unvarying form, while its outskirts, or the subgenera whereby it passes into other families, are diverse in appearance, and contain but few species. In the 'Entomological Magazine' (vols. ii. and iii.), and in the 'Monographia Chalciditum' (vol. i.), I have attempted to describe the characters of the British species of this genus, and to indicate their divisions into groups. In the second volume of the last-mentioned work, and in some numbers of the 'Annals of Natural History,' I have mentioned several exotic species. The characters that I have given are defective, owing to the omission of the structure of the metathorax or propodeon. The antennæ in the following species are nearly similar in structure; the first joint is long and slender; the second is cyathiform; the third and fourth are very minute; the following joints to the tenth successively decrease in length. The head and thorax are finely squameous; the abdomen is smooth.

Preromalus Acrotatus, fem. Viridis, abdomine cupreo, antennis piceis, pedibus fulvis, coxis femoribusque basi viridibus, alis fuscis.

Corp. long. lin. 1 ; alar. lin. $1 \frac{1}{2}$.

Body shining, rather short: head and thorax green : head broader than the thorax : antennæ clavate, dark piceous, a little longer than the thorax; first joint fulvous; club conical, vol. $\mathrm{Xx}$. 
not broader than the tenth joint but twice its length : thorax elliptical : prothorax short: scutum of the mesothorax rather long; sutures of the parapsides indistinct; scutellum having no trace of a transverse suture: propodeon obconic, declining: podeon very short: abdomen round, cupreous, depressed above, keeled beneath, hardly more than half the length of the thorax; octoon and following segments shorter than the metapodeon : legs fulvous; coxæ and thighs green; tips of the latter fulvous : wings fuscous; nervures fuscous; ulna hardly half the length of the humerus; radius as long as the ulna; cubitus shorter than the radius; stigma very small.

Found in July near Lanark, Scotland.

It belongs to the second division of the genus (Ent. Mag. ii. 479), and is allied to $\boldsymbol{P t}$. Catillus and to $\boldsymbol{P t}$. Discus, from which species it may be distinguished by its more slender structure.

Pteromalus Bubaris, fem. Æneo-viridis, abdomine cupreo, antennis nigris, pedibus fulvis, femoribus fusco-cinctis, alis limpidis.

Corp. long. lin. $\frac{2}{5}$; alar. lin. $1 \frac{1}{4}$.

Body linear: head green, broader than the thorax: antennæ black, subclavate, as long as the thorax; first joint fulvous; club fusiform, more than twice the length of the tenth joint: thorax oval, æneous-green : prothorax very short: sutures of the parapsides indistinct; scutellum obconic, having an indistinct transverse suture near its tip : propodeon obconic, declining: podeon very short: abdomen oval, cupreous, smooth, depressed above, keeled beneath, green towards the base, a little shorter than the thorax; metapodeon of moderate size; octoon and following segments short: legs fulvous; coxæ green; a broad fuscous band across each thigh; tips of the tarsi fuscous : wings limpid, rather short; nervures fulvous; ulna more than half the length of the humerus; radius shorter than the ulna; cubitus a little shorter than the radius; stigma extremely small.

Found near Edinburgh by Dr. Greville.

Allied to Pt. Lucilla (Monographia Chalciditum, i. 231), but differing from it in structure and in colour.

Pteromalus Ection, mas. Viridis, scutello æneo-viridi, abdomine nigro-cupreo basi fulvo maculato, pedibus fulvis, femoribus piceis, alis fuscis.

Corp. long. lin. 1 ; alar. lin. $1 \frac{1}{2}$.

Body slender : head and thorax dark green : head a little broader than the thorax : antennæ black, slender, filiform, a little longer than the thorax; club fusiform, twice the length 
of the tenth joint: thorax elliptical: prothorax transverse, short: scutum of the mesothorax broad; sutures of the parapsides indistinct; axillæ triangular, large, not complete; scutellum conical, æneous-green, having a slight trace of a transverse suture near its tip : propodeon obconical, declining, rather large: podeon very short, but distinct: abdomen cupreous-black, shining, depressed, increasing in breadth from its base till near its tip, having an obscure fulvous spot near its base, rather shorter and narrower than the thorax; metapodeon of moderate length; octoon and following segments shorter than the metapodeon: legs fulvous; coxæ green; thighs piceous, their tips fulvous: wings fuscous; nervures piceous; humerus much less than half the length of the wing; ulna more than half the length of the humerus; radius rather longer than the ulna; cubitus slightly curved, about half the length of the radius; stigma very small.

Found by Dr. Greville near Edinburgh.

In the structure of the prothorax, the scutellum and the podeon, it approaches the genus Trigonoderus, Westwood.

Pteromalus Xanthe, mas. Viridis, abdominis disco æneo, antemis piceis, pedibus fulvis, femoribus piceis, tarsis flavis, alis limpidis.

Corp. long. lin. $1 \frac{1}{4}$; alar. lin. $1 \frac{2}{5}$.

Body linear, bright green : head transverse, dark green, a little broader than the thorax : antennæ piceous, filiform, as long as the thorax; first joint fulvous, piceous towards the tip; fifth and following joints linear; club fusiform, twice the length of the tenth joint: thorax elliptical, inclining to æneous along the sutures : prothorax very short: scutum broad; sutures of the parapsides indistinct; axillæ large, triangular, not complete; scutellum obconical, having a cupreous band across it, but with no trace of a suture: propodeon obconical, declining: podeon very short: abdomen shining, depressed, increasing in breadth towards the tip, which is very minutely squameous, a little shorter and narrower than the thorax; disc æneous; metapodeon of moderate length; octoon and following segments shorter than the metapodeon, successively decreasing in length until the telum: legs fulvous; coxæ green; middle and hind legs with piceous thighs, yellow knees and tarsi, the tips of the latter fuscous: wings limpid; nervures piceous; humerus much less than half the length of the wing; ulna hardly more than half the length of the humerus; radius a little shorter than the ulna; cubitus much shorter than the radius; stigma small.

Found by Dr. Greville near Edinburgh.

Nearly allied to Pt. Coryphe (Monographia Chalciditum, i. 266). 
Pteromalus Aollius, mas. Viridis, scutello viridi-æneo, antennis fuscis, basi viridibus, pedibus fulvis, coxis femoribusque viridibus, tibiis fusco-cinctis, alis limpidis.

Corp. long. lin. $\frac{2}{3}-\frac{3}{4}$; alar. lin. $1-1 \frac{1}{4}$.

Body nearly linear: head and thorax bluish-green: head a little broader than the thorax: antennæ subclavate, slender, fuscous, as long as the thorax; first joint green; club elliptical, more than twice the length of the tenth joint: thorax oval: prothorax very short : sutures of the parapsides indistinct; scutellum obconic, æneous-green : propodeon obconic, æneous, declining : podeon very short : abdomen nearly linear, depressed, shining, dark æneous-green, rather shorter and narrower than the thorax; metapodeon of moderate size; octoon and following segments shorter: legs fulvous; coxæ and thighs green; a broad fuscous band across each tibia: wings limpid; nervures fuscous; humerus much less than half the length of the wing; ulna a little more than half the length of the humerus; radius shorter than the ulna; cubitus a little shorter than the radius; stigma very small,

September; North Wales.

Its structure approaches that of the first division of Pteromalus (Entomological Magazine, ii. 477).

Pteromalus Antho, mas. Viridis, abdomine purpureo, antennis nigris, pedibus piceis, femoribus viridibus, alis sublimpidis.

Corp. long. lin. 1 ; alar. lin. $1 \frac{3}{4}$.

Head and thorax dark green : head broader than the thorax : antennæ filiform, black, as long as the thorax ; first joint green; club fusiform, twice the length of the tenth joint: thorax elliptical : prothorax very short: scutum broad; sutures of the parapsides very indistinct; scutellum obconical, having no traces of a transverse suture: propodeon obconical, declining, ridged lengthwise : podeon very short : abdomen linear, depressed, shining, dark purple, tinged with green towards the base, shorter and much narrower than the thorax : metapodeon larger than the following segments, which are rather short and nearly equal in size: legs piceous; coxæ and thighs green; knees fulvous : wings with a very slight fuscous tinge; nervures fuscous; ulna rather broad, hardly half the length of the humerus; radius a little shorter than the ulna; cubitus shorter than the radius; stigma of moderate size.

England. From the collection of the Rev. G. T. Rudd.

This species is allied to Pt. Favorinus (Monographia Chalciditum, i. 263), but differs in the antennæ, in the legs and in the stigma of the wing. 
Pteromalus Learchus, mas. Viridis, abdomine æneo-viridi, antennis fulvis basi flavis apice piceis, pedibus flavis, alis limpidis.

Corp. long. lin. $\frac{1}{2}$; alar. lin. $\frac{3}{4}$.

Body nearly linear: head and thorax bright green: head a little broader than the thorax: antennæ fulvous, subclavate, much longer than the thorax; joints from the first to the fourth yellow; the following joints from the fifth to the tenth short; club piceous, fusiform, more than twice the length of the tenth joint: thorax oval: prothorax very short; sutures of the parapsides indistinct; scutellum obconic, having no traces of a transverse suture: propodeon obconic, declining, rather short: podeon very short: abdomen nearly linear, depressed, shining, æneous-green, rather shorter than the thorax; metapodeon longer than the following segments, which are of moderate and nearly equal size : legs yellow; coxæ green: wings limpid or with a slight fulvous tinge; nervures yellow; ulna about half the length of the humerus; radius as long as the ulna; cubitus shorter than the radius; stigma fulvous, rather small.

Found near Edinburgh by Dr. Greville.

Pteromalus Antorides, mas. Viridis, abdomine purpureo flavo-maculato, antennis fuscis, pedibus flavis, alis limpidis.

Corp. long. lin. $1 \frac{1}{4}$; alar. lin. 2.

Head and thorax bright green, with an æneous tinge: head broader than the thorax: antennæ fuscous, filiform, rather longer than the thorax; first joint yellow; club fusiform, twice the length of the tenth joint: thorax elliptical : prothorax short: scutum broad; sutures of the parapsides indistinct; scutellum obconical, having no traces of a transverse suture : propodeon obconic, declining, ridged longitudinally : podeon very short: abdomen depressed, shining, short-oval, purple, green at the base, near which there is a large yellow spot, much shorter than the thorax; metapodeon of moderate size; octoon and following segments rather short: legs yellow; coxæ green: wings limpid; nervures yellow; ulna scarcely half the length of the humerus; radius as long as the ulna; cubitus much shorter than the radius; stigma very small.

England. From the collection of the Rev. G. T. Rudd.

Nearly allied to Pt. Ortalus (Mon. Chal. i. 241), but it has a shorter and broader abdomen, and a smaller stigma.

Pteromalus Jaravus, fem. Viridis, abdomine cyaneo-viridi disco cuprea, antennis piceis, pedibus flavis, femoribus viridibus, alis limpidis.

Corp. long. lin. $1 \frac{1}{4}$; alar. lin. 2. 
Head and thorax green, convex : head broader than the thorax : antennæ piceous, clavate, rather longer than the thorax; first joint fulvous; club conical, flat, more than twice the length of the tenth joint: thorax oval: prothorax very short: scutum of the mesothorax broad; sutures of the parapsides indistinct; scutellum subrhomboidal, having no traces of a transverse suture : propodeon rather large, furrowed, obconic, declining: podeon very short: abdomen elliptical, bluish-green, shining, depressed above, keeled and angular beneath, attenuated towards the tip, longer and rather narrower than the thorax; disc cupreous; metapodeon of moderate length; octoon and following segments short: legs yellow; coxæ and thighs green; tips of the tarsi fuscous: wings limpid; nervures fulvous; humerus twice the length of the ulna; radius rather longer than the ulna; cubitus much shorter than the ulna; stigma small.

England. From the collection of the Rev. G. T. Rudd.

Allied to Pt. diversus (Ent. Mag. iii. 483).

Pteromalus Anaxenor, fem. Viridis, abdominis disco cyaneo-viridi, antennis nigris, pedibus fulvis fusco-cinctis, tarsis flavis, alis limpidis.

Corp. long. lin. $1 \frac{2}{3}$; alar. lin. 3 .

Body green, rather broad: head as broad as the thorax : antennæ clavate, black, pubescent, shorter than the thorax; first joint fulvous towards the base; club conical, twice the length of the tenth joint: thorax elliptical: prothorax very short: scutum broad; sutures of the parapsides indistinct; axillæ large, not conniving; scutellum subrhomboidal, having a very slight trace of a transverse impression near its tip: propodeon large, obconic, declining, indistinctly furrowed lengthwise: podeon distinct, but very short : abdomen short-oval, shining, concave above, deeply keeled beneath, much broader and shorter than the thorax; disc bluish-green; metapodeon large; octoon and following segments transverse, short: legs fulvous; coxæ green; a broad fuscous band across each thigh and tibia, but very indistinct on the protibiæ; mesotarsi and metatarsi pale yellow, fuscous towards their tips: wings ample, slightly fuscous; nervures fuscous; humerus twice the length of the ulna; radius rather longer than the ulna; cubitus a little shorter than the ulna; stigma small.

England. From the collection of the Rev. G. T. Rudd.

This species has a slight trace of the transverse furrow on the scutellum of the mesothorax, which character is developed in the genera Scladerma and Lamprotatus.

Pteromalus Tedanius, fem. Viridis, abdomine basi fulvo, antennis piceis, pedibus flavis, alis subfulvis. 
Corp. long. lin. 1 ; alar. lin. $1 \frac{3}{4}$.

Head and thorax green : head a little broader than the thorax; front large: antennæ piceous, subclavate, a little longer than the thorax; first joint fulvous; club conical, flat, more than twice the length of the tenth joint: thorax oval: prothorax very short: scutum of the mesothorax broad; sutures of the parapsides indistinct; scutellum rhomboidal, having no traces of a transverse suture : propodeon obconical, declining, rather short: podeon very short: abdomen elliptical, smooth, depressed above, keeled beneath, fulvous towards the base, green towards the tip, longer but hardly narrower than the thorax ; metapodeon of moderate size; octoon and following segments shorter : legs bright yellow; tips of the tarsi fulvous : wings slightly fulvous; nervures fulvous; ulna rather thick, about half the length of the humerus; radius as long as the ulna; cubitus shorter than the radius; stigma small.

England. From the collection of the Rev. G. T. Rudd.

Allied to Pt. discolor (Ent. Mag. iii. 473), but very different in colour.

Pteromalus Naubolus, fem. Viridis, abdominis disco cupreo, antennis piceis, pedibus flavis, femoribus viridibus, alis limpidis.

Corp. long. lin. 1-1 $\frac{1}{4}$; alar. lin. $1 \frac{3}{4}-2$.

Bright green: head and thorax convex, finely squameous: head as broad as the thorax: antennæ subclavate, piceous, as long as the thorax; first joint fulvous; club conical, twice the length of the tenth joint: thorax oval : prothorax very short: scutum of the mesothorax broad; sutures of the parapsides indistinct; scutellum subrhomboidal : propodeon short, transverse, declining, narrower towards its tip : podeon very short: abdomen elliptical, shining, depressed above, slightly keeled beneath for about twothirds of its length from the base, much longer but hardly narrower than the thorax; disc cupreous; metapodeon of moderate length; octoon and following segments shorter: legs pale yellow; coxæ and thighs green : wings limpid; nervures fulvous; ulna rather thick, about half the length of the humerus; radius nearly as long as the ulna; cubitus shorter than the radius; stigma pale fuscous, of moderate size.

From the collection of the Rev. G. T. Rudd.

This species has a larger stigma than Pt. Amyntor (List of Chalcidites in the British Museum, p. 48) and Pt. linearis (Ent. Mag. iii. 189), to which it is allied. It much resembles Pt. semifascia (Ent. Mag. ii. 494), but wants the stripe on the upper wing which distinguishes the latter. 
Pteromalus Aglaus, mas. Viridis, abdomine cupreo basi viridi, antennis piceis, pedibus fulvis, femoribus fusco-cinctis, alis limpidis.

Corp. long. lin. $\frac{2}{3}$; alar. lin. 1 .

Body rather narrow: head and thorax green: head a little broader than the thorax: antennæ filiform, piceous, a little longer than the thorax; first joint fulvous towards the base; club fusiform, more than twice the length of the tenth joint: thorax elliptical: prothorax short: scutum of the mesothorax rather long; sutures of the parapsides indistinct; scutellum subrhomboidal : propodeon large, short-obconical, declining, having three longitudinal striæ: podeon very short: abdomen elliptical, depressed, cupreous, shining, narrower and much shorter than the thorax; metapodeon green, rather large; octoon and following segments short: legs fulvous; coxæ green; tips of the tarsi piceous; a broad fuscous band across each of the hind thighs: wings limpid, rather narrow; nervures fulvous; humerus nearly twice the length of the ulna; radius shorter than the ulna; cubitus shorter than the radius; stigma very small.

July, near London.

It has some resemblance to Pt. Pronax (Monographia Chalciditum, i. 224).

Pteromalus Urgo, fem. Cyaneo-viridis, abdominis segmentis basi purpureis, antennis piceis, pedibus flavis, femoribus viridibus, alis limpidis.

Corp. long. lin. $1 \frac{1}{4}$; alar. lin. $1 \frac{3}{4}$.

Head and thorax bluish-green : head not broader than the thorax : antennæ piceous, subclavate, rather shorter than the thorax; first joint fulvous; club conical, flat, twice the length of the tenth joint: thorax oval: prothorax very short: scutum of the mesothorax large; sutures of the parapsides very indistinct; scutellum subrhomboidal: propodeon rather short, declining, narrower behind: podeon very short: abdomen fusiform, shining, green, slightly compressed, concave above, keeled beneath, rather narrower and very much longer than the thorax; metapodeon of moderate size; octoon and following segments shorter, some of them purple on the disc, excepting the hind border: legs yellow; coxæ and thighs green; tips of the tarsi piceous : wings limpid; nervures yellow; humerus much more than twice the length of the ulna; radius longer than the ulna; cubitus rather shorter than the ulna; stigma very small.

From the collection of the Rev. G. T. Rudd.

Differs slightly from Pt. Amyntor (List of Chalcidites in the British $\mathrm{Mu}$ seum, p. 48). 
Pteromalus Orinus, fem. Viridis, abdomine cupreo basi viridi, antennis fuscis pedibus fulvis, femoribus viridibus, alis limpidis.

Corp. long. lin. $\frac{3}{4}$; alar. lin. $1 \frac{1}{4}$.

Head and thorax green: head a little broader than the thorax : antennæ slender, subclavate, fuscous, rather longer than the thorax; first joint fulvous; club conical, twice the length of the tenth joint: thorax oval: prothorax very short: scutum of the mesothorax almost flat; sutures of the parapsides indistinct; scutellum subrhomboidal, having a slight trace of a transverse suture: propodeon of moderate size, obconical, declining, finely squameous : podeon very short : abdomen elliptical, cupreous, shining, depressed above, slightly keeled beneath, green towards the base, narrower but not longer than the thorax; metapodeon of moderate length; octoon and following segments shorter: legs pale fulvous; coxæ and thighs green, tips of the latter fulvous; tips of the tarsi fuscous: wings limpid; nervures fulvous; humerus twice the length of the ulna; radius longer than the ulna; cubitus rather shorter than the radius; stigma very small.

Found near London.

Allied to Pt. latifrons (Ent. Mag. ii. 501).

\section{Scladerma, Walker.}

Scladerma Lalage, fem. Viridis, abdomine cyaneo, antennis nigris, pedibus fulvis, femoribus viridibus, tibiis tarsisque apice fuscis, alis sublimpidis.

Corp. long. lin. $1 \frac{1}{4}$; alar. lin. $2 \frac{1}{2}$.

Head and thorax bright green, convex, finely squameous : head a little broader than the thorax: antennæ subclavate, black, rather longer than the thorax; first joint long, slender, green; second long-cyathiform; third and fourth very minute; fifth and following joints to the tenth successively decreasing in length; club fusiform, much longer than the tenth joint: thorax elliptical : prothorax rather short, narrower in front: scutum of the mesothorax long; sutures of the parapsides very distinct; scutellum subrhomboidal, bluish-green, having a distinct transverse suture near its tip; axillæ large, nearly meeting between the scutum and the scutellum: propodeon large, obconical, declining, slightly ridged: podeon very short, but distinct: abdomen oval, blue, almost flat above, deeply keeled beneath, much shorter than the thorax; metapodeon rather large, conical, concave along the disc; octoon and following segments short, their hind borders cupreous : legs fulvous; coxæ and thighs green, tips of the latter fulvous; tips of the tibiæ and of the tarsi of the middle and of the hind legs VOL. XX. 
piceous : wings nearly limpid; nervures piceous; humerus a little more than twice the length of the ulna; radius very much longer than the ulna; cubitus much shorter than the ulna; stigma of moderate size.

Found by Dr. Greville near Edinburgh.

It is nearly allied to $S$. convexum (Ent. Mag. ii. 290).

I add a few words in explanation of the terms, not in general use, which I have employed for describing the parts of insects in the preceding pages :

Propedes, or fore legs.

Mesopedes, or middle legs.

Metapedes, or hind legs.

Proalæ, or fore wings.

Metalæ, or hind wings.

Propodeon, or the segment between the metathorax and the petiole.

Podeon, or the petiole.

Metapodeon, or the first segment of the abdomen.

Octoon, or the second ditto.

Ennaton, or the third ditto.

Decaton, or the fourth ditto.

Protelum, or the fifth ditto.

Paratelum, or the sixth ditto.

Telum, or the seventh ditto.

-See the 'Entomological Magazine,' vol, i. p. 400, \&c. 


\section{$2 \mathrm{BHL}$ Biodiversity Heritage Library}

Walker, Francis. 1846. "Descriptions of Chalcidites." Transactions of the Linnean Society of London 20, 153-162.

https://doi.org/10.1111/j.1096-3642.1846.tb00415.x.

View This Item Online: https://www.biodiversitylibrary.org/item/19393

DOI: https://doi.org/10.1111/j.1096-3642.1846.tb00415.x

Permalink: https://www.biodiversitylibrary.org/partpdf/22987

\section{Holding Institution}

Natural History Museum Library, London

\section{Sponsored by}

Natural History Museum Library, London

\section{Copyright \& Reuse}

Copyright Status: Public domain. The BHL considers that this work is no longer under copyright protection.

This document was created from content at the Biodiversity Heritage Library, the world's largest open access digital library for biodiversity literature and archives. Visit BHL at https://www.biodiversitylibrary.org. 